ÉGYPTE monde arabe

\section{Égypte/Monde arabe}

$6 \mid 2003$

D'une intifâda l'autre. La Palestine au quotidien

\title{
Letters from the Palestinian Ghetto 8-13th March 2002
}

\section{Lena Jayyusi}

\section{OpenEdition}

1 Journals

Édition électronique

URL : https://journals.openedition.org/ema/936

DOI : $10.4000 /$ ema.936

ISSN : 2090-7273

\section{Éditeur}

CEDEJ - Centre d'études et de documentation économiques juridiques et sociales

\section{Édition imprimée}

Date de publication : 31 décembre 2003

Pagination : 125-129

ISBN : 2-87027-993-0

ISSN : 1110-5097

\section{Référence électronique}

Lena Jayyusi, «Letters from the Palestinian Ghetto 8-13th March 2002 », Égypte/Monde arabe [En ligne], 6 | 2003, mis en ligne le 08 juillet 2008, consulté le 07 juillet 2022. URL : http://

journals.openedition.org/ema/936; DOI : https://doi.org/10.4000/ema.936

Ce document a été généré automatiquement le 7 juillet 2022.

Tous droits réservés 


\title{
Letters from the Palestinian Ghetto 8-13th March 2002
}

\author{
Lena Jayyusi
}

1 The principle of non-simultaneity. It is wonderful to hear children laugh down the stairs of our building. After months in which all sounds were banished from the place, save for the imagined and remembered sounds of shelling from the green-dressed army camp across the valley, the sense of normalcy creeps back, albeit only in doses. But children's laughter in the here-and-now inhabits one dimension; normalcy, the taken for granted and yet plannable course of quotidian life, inhabits the point at which dimensions intersect. I know it will not yet be a constituent of our compass of existence here. As the laughter trips down the staircase, at this very moment, in the refugee camp of Tulkarm, in the Aida and Dheisheh camps of Bethlehem, in the already partly destroyed neighborhoods of Rafah, children are hearing the continuous sound of heavy fire, of planes and helicopters that pierce the ceiling of their world with a ferocity of surveillance and destruction. Not like children in the spaces over there, across the Atlantic, where the weapons are manufactured, where the master decisions and policies are made, where the new regime of domination is being secured and perfected. The principle of non-simultaneity: the existential condition which, in a world traversed by the cruelty and blindness of power, must be overcome. Solidarity.

2 They will come to Ramallah soon enough... they will pass again with their gunfire close to this very place, this building. This neighborhood lies on the route of a probable entry point for their invasion force : it will not be the prime target, but will stand as part of the landscape to be mastered. The target will be the refugee camps: Al Amari can be reached down the road from here. My sister asks me to go over to her in Jerusalem. But I have no wish to leave ... finally I understand the ordinary refusal to budge. My fear, which will no doubt raise its haunting head at the zero hour, is docile at present, prior to that inevitable moment; what raises its head insistently is refusal. What moves through my body is not the gut-clenching fist of dread, not yet, but the catapulting jolt of anger. And the will to simultaneity. How am I to leave? How many can leave the camps? Can I forget the shame I felt that night, months ago, when I first crouched in a 
corner of the middle room, with machine-gun fire battering the walls of the building, battering my ears and memory? The wild fear I felt and the shame that came with it, provoked by the thought of that much more terrible and palpable hell of Beirut during the three months of Israel's assault and siege in the summer of ' 82 ? The summer my new born child finally came home: then too I could only grapple with nonsimultaneity, I could only choose to acknowledge and refuse it at the same time.

The Israeli Leviathan continues to exact its toll, continues to march through our lives, the small moments and the great, all marked by its imprints, the sound of its machinery. The moment of birth, the wedding, the shopping trip, the reunion with those we miss most - these were always and deeply marked long long before Oslo, and right through the period of pseudo - grace that was Oslo, the phase when we were being dressed for the final ceremony. Everyone cheering in the gallery, while we were being gathered in the stadium. While the bounds and latitudes of the meta-colony were being drawn,

4 We are getting used to this... this periodic assault of death at the hands of the Israeli army, and its allies ; this fearful stream of dying, of bodies carried on the shoulders of friends and kin. Every few years we live through an interminable age of aching, an upheaval of loss, when a smile seems a distant object, a dance an impossible dream, when our whole world is forcefully plunged, once more, into a punishment of killing by a power which demands we cease to dream, punishes us for daring to will a future of our own. We are getting used to this : patience limping soul, stand steadfast, or these young bodies, and these old ones, broken by fire, will not release the freedom of their spirit. Patience, even as we wake up to the toll, sleep to the toll, every cell aching to fashion a new reality. March $8,2002 \ldots$ oh, the impossible green of their banner-covered coffins, rows of them, carried by the crowds, all of them already their brothers. Already fifty today. A tumult of the collective will to live and to be. We are getting used to this.

5 They shoot at will. They kill civilians and say they are terrorists planning to carry out operations. They drive over ambulance cars with their tanks; shoot at the ambulances to prevent them from picking up the injured, killing the doctors and the emergency personnel and deliberately leaving the wounded to bleed slowly in the streets, in the corners where they were picked out, to bleed until they die. Their tanks storm the small corridors of the camps, shattering the frail rooms of the already dispossessed, destroying lives, gutting neighbourhoods, intending to terrorize a new generation. This is a population which for 53 years now has been hounded by those who conquered their land and homes... The witness, the dispossessed, must be dissuaded from demanding restitution; must be broken so that the world is not reminded, prodded to rehabilitate... Such systematic, insistent and heavily muscled cruelty used to have a name. I still call it fascism: the entire range of military, political, economic, and mediational instrumentalities converging to crush the adversary, to penetrate, shape and master the entire range of ordinary living in the world. The fascism at the heart of all colonial order unmasked by resistance, by an indigenous population awoken to its own rhythms.

6 The bubble of the meta-colony has been punctured. The colonial machine is at full throttle. And the silence of the many fills the great void of the sky. They have come to settle from all over the world, and now stand on all the corners of the country, at all the entry points to our lives. Tonight, after only one hour in Jebalya camp, in Gaza, eleven killed, fifty wounded. According to the report they stand with their invasion 
force on all the entrances to Ramallah, This small room I have prepared in the middle of the flat is a palace... how small I feel, unable really to share and do. I declined to stay at Raji and Rose's place tonight, where earlier we had spent some hours of the evening, despite their insistence and the report of tens of tanks on their way. They would not come over to my place after tanks made their appearance on the bypass road below their home. Almost twenty of them. Khadîja who left at the same time as I did lives right opposite Psagot, the furious settlement which belched missiles all through the recent months at homes, school, gym in al-Bireh. She too declined to come over. She has lived through Black September, the siege if Beirut. We laugh with each other over the phone... if you need anything at any point I am here. But we're all in it, like everyone else. Areej, much younger than any of us, has the same feeling. We all stay put. What happens to all, happens to each. But it is not entirely true. Down there in the refugee camps, down there they will receive the fury that inhabits the fear, and animates the will to crush, that the colonizer always vents. They will receive the depleted uranium, the heavy missiles, the columns of tanks smashing though the small alleys, the army which will bore through the walls of the close bordered homes, down there the real battle, the big toll will be had. The refugee camps. The very mark of our condition, the sign of the original deed which catapulted us all into this unending journey, the embodiment of what might have been, what was, what could be, the body which must be dismembered for so many to breathe lightly, rest back in comfort. The body within our body, the representation of our memory. The actual face of the encounter which has ceaselessly been miscast and untold over the years, but which will not stop telling itself to anyone who will look in its eyes.

7 The radio broadcast, the Voice of Palestine transmitting from its new location, has suddenly stopped. I know what that means. Heavy gunfire. My heart beats fast. Who will lie bleeding tonight, ambulances prevented from reaching them? How many will die here? How many will be led away, like they were yesterday in Qalqilya, all males between the ages of fifteen and fifty rounded up, blindfolded, their arms marked. with numbers. Always the marking. Stripped, interrogated, and beaten, led away for more to the place of concentration. Like they were twenty years ago in the sports stadium in Beirut. I cannot help remembering. I cannot help remembering Santiago, as well, Sarajevo, Srebrenica. Steps on the ladder to hell. For us who receive and resist. And yet resist after each new step... And for them who come to batter us...

8 The tanks have surrounded the hospitals in Ramallah. They shoot at the medical staff. They shoot at the reporters. They have entered the camps. They are stationed everywhere. We cannot move. A long, very long way away, Anan talks of «the unnecessary use of lethal force ». There is then a necessary measure of lethal force that the Israeli war machine can wreak on us in our own land. On the BBC, on CNN, anchors and reporters talk to the world of «the cycle of violence ». Equal and equivalent. The new stack of phrases that position you endlessly on the road to nowhere, the occupation itself effectively sanitized and packaged, institutionalized and countenanced. As it was from the very first years - the "benign occupation ». The accumulated utterances of decades of deliberate or uncaring collusion. The deeds of denial. The deeds which dovetail with the systematics of violence, of negation, and the decades long project of undoing an entire society.

9 The shooting is right below us now. The building is hit. Again. At moments like these, all the solidities around you, beneath you, turn fluid. A fluidity which threatens to 
drown the senses. Every part of your body takes on a life of its own; your ear rushes at every sound, dizzying your hold on what immediately surrounds you. I understand what my friend meant when he said that at the moment when death hangs in the air, the only person who is not under its spell is the one who is engaged with it, actively resisting it.

The tanks have surrounded all the hospitals. In the maternity hospital, five women are waiting for help with difficult deliveries, but the doctors cannot get there. Upstairs, on the third floor, my neighbors have their young cousin staying with them. She is due in a few days. She is a breach birth. If she goes into labour now, she will not make it. A few days ago, a young woman died at the checkpoint, giving birth. And the baby. The soldiers would not let her through.

11 Occupation is violence. How is it that this truth seems to have fallen into the shadows? That at the gateway to this heralded new century, a condition of outright corporeal oppression should be redefined through the suppression of the manifold details of daily policy, and represented merely through the foggy optic of «the need to return to the negotiating table »? The reductive logic of an overtly detached, secretly invested ethic. To negotiate what? A limited measure of freedom from the limiting constraints of occupation? An occupation that persists and increasingly insists on consuming and appropriating place and space, land, air and water. An occupation in the service of a colonial order, of a colonial will to erase, marginalize, silence, replace, and dispose at will. Colonialism is a project of violence. How is it that this knowledge is discarded, violated and inverted? Already, centuries of colonial experience-the small details of terror inflicted on the body in and of the everyday; that erupt with ferocity at every intersection where collective wills confront each other. What allows this historical memory to be excommunicated? Official Europe straddles the full spectrum of complicity : the acknowledging gesture empty of the act; the silence; the continued investment in the relationship with the colonial state. It has not dismantled its colonial ethos. The Arab order straddles the full spectrum of complicity. With even greater injury. It has not reconfigured its colonial psyche. The USA is on its imperial march.

The tanks surrounding the hospitals have blocked their entrances, preventing the wounded from being brought in for treatment. Their water and electricity supplies have been cut off, needed oxygen cylinders prevented from delivery. A death sentence. The doctors say they will operate on the wounded in the streets, in front of the tanks. Families in Ramallah are being prevented from burying their dead. An Israeli representative on the $\mathrm{BBC}$ announces that the infrastructure of terror is being destroyed. Palestinian violence has to be stopped. Arafat has been given permission to move as he wills in the Palestinian territories. There is no prodding question in return.

Perhaps in this day, when the powerful speak what they will, and the rest act as though this was the "truth", silence would be our best companion. It is difficult to speak in the face of the consummate lie, trumpeted and reproduced in various small details across the spectrum of the institutional means of discourse: media, politicians, academics. «The talk would talk and go so far astray... you don't want madness and the whole thing there..."

There is no constative any longer: only the pure performative. The constative, the kernel of actuality in the spine of each performative, has been vacuumed out. And the pure performative is a monstrous tool in the hands of the powerful. The performative utterance is over-determined in the age of the advanced machinery of killing, the age 
of concentration of financial power, translatable always into the power to starve and to assassinate. But the courage of ordinary people has no bounds.

What register does one speak in, when every register is contaminated? The concrete, the historical, the moral, the political, the quotidian, the existential... all these are inflected with the performance of power, and the cruelty that attaches to it. All these are distorted by the machinery of power.

16 And yet, I carry their faces with me, their voices, over and over again, saying tell them, why don't they hear, where is everyone, just like their counterparts did in Bosnia. I carry their gestures, reaching out to beckon, their proclamations, their stories their puzzlement, their resolution. Their will to be. They are all mine. I have carried them for years through the long trek of exile. After I first discovered my mother, one spring day, secretly crying, and could not understand what her words meant, « on this day, three years ago, they took my country from me ». It is hard to keep company with silence.

INDEX

Mots-clés : Palestine

\section{AUTEUR}

LENA JAYYUSI

College of Communication and Media Sciences, Université Zayed (Émirats arabes unis) 